\title{
A LAKOSSÁG KÖRNYEZETTERHELÉSÉT JELZŐ VIZSGÁLATOK
}

\section{Patocskai Mária}

Eötvös József Főiskola, Neveléstudományi Kar, Pedagógusképző Intézet

\section{Bevezetés}

A lakosság történelmi fejlődése során bár javította életfeltételeit, de tönkre is tette azokat. Ebben nagy szerepet játszott/játszik az egyre intenzívebb termelési eszközök által növekedő gazdaság, amely folyamatosan újratermelődő társadalmi igényeket generált/generál. Ezek megvalósításához egyre több anyag- és energiafelhasználás szükséges. Mivel a növekvő energiaigény fosszilis erőforrásokra épül, ezért az energiafelhasználásból származó ÜHG (üvegházhatású gáz) kibocsátás számszerüsítése megfelelő módszer lehet a környezetterhelés indikálására.

A számításokhoz a lakosság legnagyobb energiafogyasztással járó tevékenységeihez felhasznált energiamennyiségeket vettem alapul: a villamosenergiafelhasználást, a közlekedést és a fütést. Ezek alapján az ÜHG-kibocsátás hazai átlagát, valamint hét alföldi település egy före eső átlagát számoltam ki. Továbbá vizsgáltam a településtípusonkénti differenciákat. Ahhoz, hogy az eredményeket értelmezni lehessen, ezért a kapott ÜHG-értékeket először összehasonlítottam a hazai ÜHG-leltárral. További értelmezés miatt területalapúvá váltottam őket: összehasonlítottam a hazai erdők elnyelő kapacitásával. Vizsgáltam még, hogy a kiválasztott tevékenységek során felszabaduló ÜHG-k hogyan aránylanak a felhasznált energiamennyiségekhez.

Az eredmények rávilágítanak életvitelünk energiaigénylő tevékenységeiből származó környezetszennyezés mértékére: a lakosság környezeti problémákkal kapcsolatos személyes felelőssége egyáltalán nem elhanyagolható a fogyasztói felelösség mellett.

\section{Módszer}

Az ÜHG-számítás legnagyobb problémáját a számítás alapját képező adatbázis (energiamennyiségek) létrehozása jelentette.

A kutatás elején azonosítottam a legnagyobb mértékủ fosszilis erőforrásokat felhasználó lakossági tevékenységeket. Ezek határai viszonylag egyszerüen meghatározhatók, amelyek a forrásadatok miatt lényegesek. Ezek megállapításánál fontos tényező volt, hogy mely adatokhoz lehet hozzájutni, másrészt mely adatoknak ismerjük az életútját.

A lakossági energiafelhasználás alatt még a szakirodalom is minden esetben csak a fütést és a villamosenergia-használatot érti. Az általam kutatott témában a közlekedésre felhasznált energiamennyiség is vizsgált tevékenység. Ez tovább nehezítette a számítás alapját képező adatbázis létrehozását. 
A vizsgált tevékenységek határait és energiaigényüket a következőképpen húztam meg.

A villamosenergia-fogyasztáshoz a hazai áramtermelés fosszilis erőforrásainak fajtáit és mennyiségeit vettem figyelembe. Bár az ország jelentős mennyiségü villamos energiát importál, ez mégsem szerepel a számításban. Egyrészt, mert annak fosszilis összetevői számunkra ismeretlenek, másrészt megegyezés alapján ez az ÜHG-emisszió nem hazánk, hanem az előállító országot terhelné. Adatok hiánya miatt a hazai villamosenergia-termelö objektumok (atomerőmü, hőerőmüvek) müködéséből származó ÜHG-emissziók sincsenek benne a számításokban. Ezeket viszont az OMSZ által kiszámolt hazai ÜHG leltár tartalmazza.

A közlekedés vonatkozásában a lakosság saját személygépjármü használatából eredő ÜHG emissziót számoltam ki, mert fajlagosan ennek a legnagyobb a kibocsátása a tömegközlekedéshez viszonyítva.

Országosan a fütés tekintetében azt vettem figyelembe, hogy hazai vonatkozásban milyen fosszilis erőforrásokat használ a lakosság. A vizsgált települések esetén pedig földgázzal számoltam, mert egyrészt ez a domináns fütőanyag. Másrészt a fa tüzelésekor felszabaduló $\mathrm{CO}_{2}$-t nem vesszük figyelembe az asszimiláció miatt.

Az országos számításokhoz hiányzó adatok összeállítása miatt a következő országosan és nemzetközileg elismert kiadványok által közölt tényadatokat kellett összevetni: az Energiaközpont Nonprofit Kft. háztartásokra és közlekedésre vonatkozó energiafogyasztásait, a KSH 2009 energiafogyasztásokra, valamint az Odyssee (27 európai ország energiára vonatkozó mutatóit gyüjti össze, nyomon követi az energiahatékonysági trendeket és politikai intézkedéseket) vonatkozó jelentéseit. Probléma volt, hogy az adatok legtöbbször eltérő tartalommal, definícióval és kategorizálással jelentek meg az egyes adatbázisokban. Emiatt logikai következtetésekkel, számításokkal, adatok harmonizációjával, közös mértékegységre hozásával jutottam a forrásadatokhoz.

Az ÜHG számításokat a hazai lakosságra és néhány településre (Baja, Kalocsa, Érsekcsanád, Rém, Sükösd, Nemesnádudvar és Dusnok) vonatkozóan készítettem el. Az ÜHG-k kiszámításának alapja minden esetben ugyanazon a kémiai folyamaton alapszik. Eszerint a fosszilis erőforrásban levő szén az égés során oxidálódik és így keletkeznek az ÜHG-k. A legtöbb szén $\mathrm{CO}_{2}$ formájában kerül kibocsátásra, kisebb része $\mathrm{CO}, \mathrm{CH}_{4}$, illetve nem-metános illó szerves vegyületekként. Ezek alapján a számítás általános módszertana, hogy a tevékenységi adat (energiamennyiség) és az emissziós faktor szorzataként kapjuk meg az emissziót: Emisszió = tevékenységi adat $\times$ emissziós faktor

Mindhárom tevékenységből származó ÜHG-kibocsátás eredményei a 2009es évre vonatkoznak, mert visszamenőleg ez az utolsó év, hogy mindhárom tevékenység esetén egységesen a kiindulási adatokat össze tudtam állítani. A számítások a $\mathrm{CO}_{2}, \mathrm{CH}_{4}$ és $\mathrm{N}_{2} \mathrm{O}$ emissziókra vonatkoznak, mert a vizsgált tevékenységek során ezekből jut a légkörbe a legnagyobb mennyiség. A végső 
eredményeket $\mathrm{CO}_{2}$ e-ben (szén-dioxid-egyenértékben) fejeztem ki és egy lakosra vonatkoznak, ezek az összehasonlítás alapjai.

A hazai számításokhoz szükséges forrásadatok létrehozása miatt a következő lépéseket dolgoztam ki a vizsgált tevékenységekre vonatkozólag.

A hazai villamosenergia-termelés különböző mennyiségü, fajtájú és másmás ÜHG-emissziós-faktorú fosszilis erőforrásokból származik. Ezért először a fosszilis erőforrás energiamennyiségeinek adatbázisát kellett létrehozni, majd az egyes összetevőkre vonatkozó emissziós faktorokkal szorozva kaptam meg a lakossági felhasználás országos eredményeit. A települések esetén azt a problémát kellett megoldani, hogy hogyan lehet érvényesíteni az országos villamosenergiatermelés fosszilis erőforrás fajtáit és mennyiségeit településekre vonatkozólag, miközben kész adatként csak a települések villamosenergia-fogyasztása állt rendelkezésemre kWh-ban. Ennek megoldására a következő elgondolás szerint számoltam: az egyes települések kWh fogyasztását arányítottam az országos $\mathrm{kWh}$ fogyasztáshoz. Az így kapott minden egyes településre vonatkozó arányszámmal szoroztam az országos ÜHG emisszió értékét, mivel minden fogyasztó ugyanolyan fosszilis erőforrás arány égetésével kapja a villamos energiát.

A közlekedés országos és településekre vonatkozó ÜHG-emisszióinak kiszámításánál a kiindulási adat az elhasznált üzemanyagok mennyisége. Erre vonatkozólag egyáltalán nem állt rendelkezésre kész adat.

Az országos lakossági közlekedés ÜHG-emissziójához először a hazai közlekedési ágazatból a lakosságra vonatkozó üzemanyag fogyasztás adatait kellett összeállítani. Ezek benzinre és gázolajra vonatkozólag ktoe (kilotonnaolajegyenérték)-ben szerepeltek, amelyeket egy lakosra jutó üzemanyag fogyasztásra (kg/fö) kellett átváltani, ezért többszöri átszámítással kaptam meg az ÜHGemisszió kiszámításához szükséges kiindulási adatokat. Ezek alapján az 1 lakosra jutó országos átlag üzemanyag fogyasztást a következőképpen számoltam ki:

$$
1 \text { lakosra jutó üzemanyag-fogyasztás }\left(\mathrm{kg} / f_{0}^{\prime \prime}\right)=\frac{\text { Eországos ïzemanyag-fogyasztás }\left(\mathrm{kg} / f_{0}^{\prime \prime}\right)}{\text { országos népesség }\left(f_{0}^{\prime \prime}\right)}
$$

A települések lakossági közlekedéséből származó ÜHG-kibocsátás kiszámítását az nehezítette, hogy egyedüli adatként a települések népességszáma és a benzin, valamint gázolaj üzemü személyautók darabszáma állt rendelkezésre kész adatként. Ugyanakkor számomra a vizsgált település egy lakosára vonatkozó átlag üzemanyag fogyasztása volt szükséges. Ennek megoldására a következő számítást tartottam megfelelőnek: 


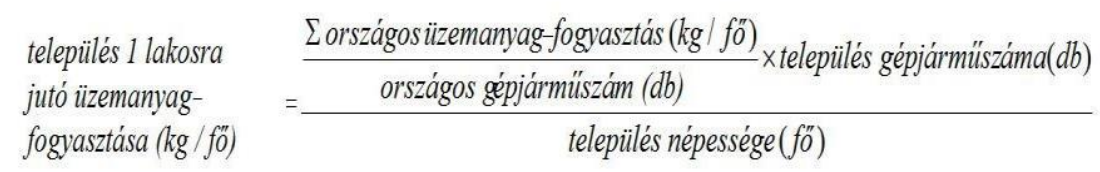

Az országos lakossági fütés emissziójának kiszámításának az alapja, hogy milyen és mennyi fosszilis tüzelöanyagot használ a hazai lakosság. Ezek energiamennyiségeinek $1 \mathrm{~kg} /$ fö-re átváltott értékeit szorozzuk az adott energiahordozó fütőértékével és emissziós faktorával.

A kiválasztott települések fütéssel kapcsolatos emisszió kiszámításánál a településekre vonatkozó gázfogyasztást vettem alapul, amely értékeket a fütőértékkel és az emissziós faktorral szoroztam. A fa égetéséből származó ÜHGkibocsátást egyik helyen sem vettem figyelembe a növények asszimilációja miatt.

\section{Eredmények}

\section{A hazai és a vizsgált települések ÜHG eredményei}

A kiszámolt ÜHG-kibocsátásokat az OMSZ által számított összes ÜHG-leltárhoz viszonyítottam az eredmények értelmezése végett. Ezek alapján az általam kiszámolt országos ÜHG-értékek (3292,1 kg/fö) 50,6\%-a az OMSZ által minden évben kiszámolt egy före jutó összes emberi közvetlen és közvetett tevékenységekkel összefüggő 6-7 tonna közötti kibocsátásnak (hazai ÜHG-leltár) (1. ábra).

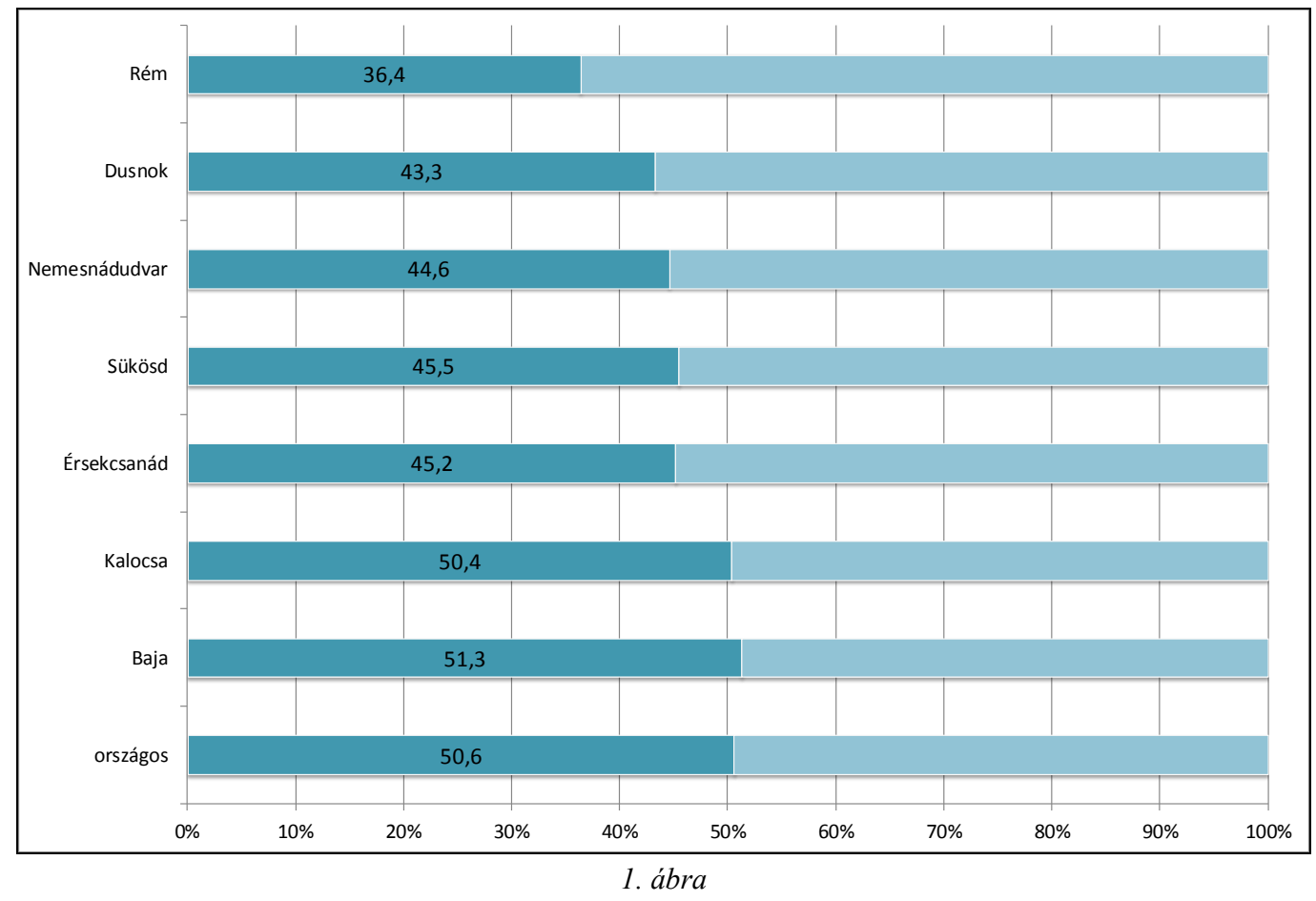

A települések ÜHG eredményei az országos ÜHG-leltár $\left(6500 \mathrm{~kg} / \mathrm{fö}^{\prime \prime}=100 \%\right)$ százalékában 
Az 50,6\% azt jelenti, hogy a lakosság életvitele által csak a közvetlen környezeti hatású tevékenységeivel: a villamosenergia-fogyasztással, a közlekedéssel és a fütéssel már fele részben hozzájárul a légkör ÜHG-kal történő terheléséhez. A másik feléhez közvetett módon járul hozzá: minden szállítás, ipari, mezőgazdasági és a szolgáltató szektorban felhasznált energia is végső soron a lakosságért használódik fel.

A vizsgált települések ÜHG-emissziói alapján három csoport különböztethető meg (1. ábra). Baján és Kalocsán közel akkora ÜHG-emisszióval élnek az emberek, mint a hazai lakosság átlagosan. A két város esetén ez az országos teljes ÜHG-leltárnak a fele. A kistelepüléseken kedvezőbbek a kibocsátások: a legkisebb emissziójú Rémen az országos teljes ÜHG-leltárnak csak 36,4\%-t, Érsekcsanád, Sükösd, Nemesnádudvar és Dusnok településeken 43-45\%-t bocsátják ki az itt élők a vizsgált tevékenységek által. Ez Rém esetén $924 \mathrm{~kg} /$ fö, a kistelepülés csoport esetén pedig 350-470 kg/fö $\mathrm{CO}_{2} \mathrm{e}$-vel (szén-dioxid-egyenértékkel) kevesebbet jelent évente lakosonként.

\section{Az ÜHG eredmények tevékenységekre lebontva}

Ha a hazai átlag ÜHG-emissziókat a tevékenységekre lebontjuk, akkor látható, hogy villamosenergia-fogyasztásból 1465,18 kg/fö, közlekedésből 836,8 kg/fó és fütésből 990,17 kg/fö $\mathrm{CO}_{2}$ e kibocsátás adódott, amelynek összege 3292,1 kg/fö (2. ábra).

Százalékos megoszlásban ez azt jelenti, hogy 44,5\%-kal a villamosenergiafogyasztással, 25,4\%-kal a közlekedéssel és 30\%-kal a fütés által járul hozzá a lakosság a légkör ÜHG terheléséhez csak e három tevékenységet alapul véve.

Ha a vizsgált települések ÜHG-értékeit hasonlítjuk össze a kiválasztott tevékenységek alapján, akkor látható, hogy a két városban közel akkora mindhárom tevékenység ÜHG-kibocsátás százalékos aránya, mint az országos átlag (lásd 2. ábra).

A villamosenergia-fogyasztásból származó magas ÜHG-kibocsátás egyrészt a hazai villamosenergia-termelés magas fosszilis erőforrás arányától $(48,6 \%)$, az összetevők fajtájától, ezek ÜHG-kra vonatkozó kedvezőtlen emissziós faktoraitól és az összetevők mennyiségétől függenek. Másrészt a magas ÜHG-kibocsátás hátterében a rendszerváltással megjelenő termelés, kínálat, de alapvetően a fogyasztási szokások drasztikus megváltozása áll. A rendszerváltással lehetővé vált a lakások elektromos készülékekkel való felszerelése a nyugati típusú fogyasztási modellnek megfelelően. Ezeket a tendenciákat városokban és falvakban egyaránt igyekszik követni a lakosság. Az ilyen jellegü fogyasztásból eredő kibocsátásokat a városi lakosság tovább emeli a légkondicionáló készülékek alkalmazása által, amit az egyre elviselhetetlenebbé váló városi klíma okoz. Mindez növeli egyrészt a villamosenergia-fogyasztást és ÜHG-kibocsátást, másrészt hatására tovább emelkedik a városi levegő hőmérséklete. 


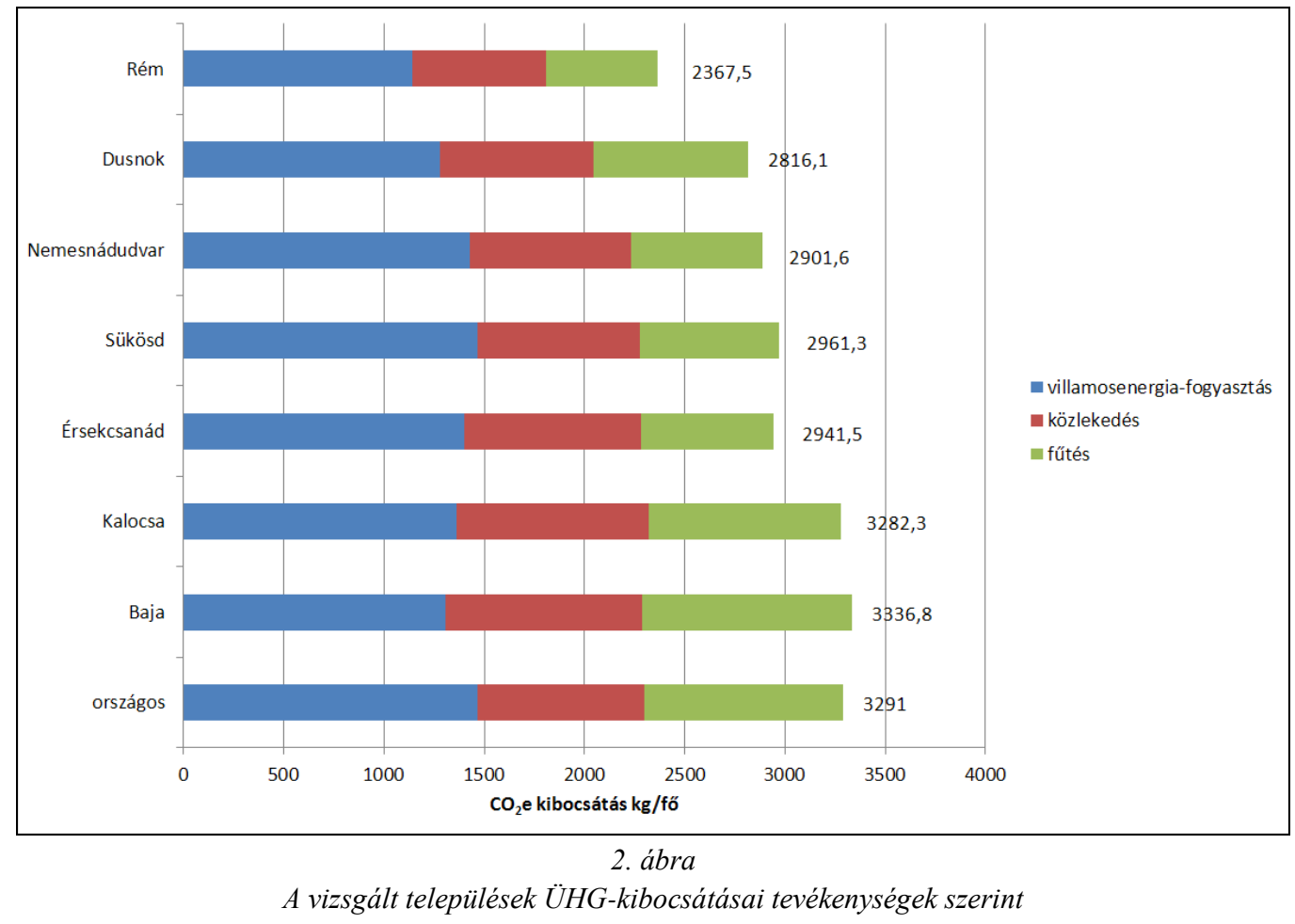

A vizsgált városok közlekedésének magas ÜHG-emissziója mögött egyrészt az 1000 lakosra jutó az országos átlagnál is magasabb személygépkocsi arány áll. Az ingázók aránya bár alacsony, ezért a lakosság mozgása döntően a városon belül zajlik. A kiválasztott városok összefüggő területe a lakosságszámhoz képest nagy, sokan a város környékén laknak. A kevésbé vagy aránylag jól müködő tömegközlekedés ellenére a személygépkocsihoz való kötődés erős, amit a használók jobb anyagi helyzete meg is enged. Ez szoros kapcsolatban áll a határközelségből eredő „fekete” gazdaság virágzásával, amely sokak számára könnyű és gyors gazdagodást hozott (Baja). A helytelen szemléletből fakadóan az autót, mint státuszszimbólumot használva az indokolatlan, öncélú autóhasználat is nagyon jellemző. Mindezek növelik a negatív környezeti paraméterek értékét is, például Baján igen magas a szálló por értéke és a zajterhelés is.

A városi fütésből adódó magas ÜHG-emisszió oka, hogy föleg a sok társasház lehetetlenné teszi a gázon kívüli, kisebb vagy nulla ÜHG-kibocsátású fütési alternatívát.

A legkisebb emissziójú Rémen mindhárom tevékenységnek jóval alacsonyabb a kibocsátása. A kisebb környezetterhelés egy takarékosabb életvitelből származik, amely a kedvezőtlen társadalmi és gazdasági kényszerhelyzet következménye. A falu egyéni közlekedésének alacsony ÜHG-emisszió hátterében az áll, hogy az aktív keresők nagy része a faluban vagy közelében dolgozik agrárkeresőként, az ingázók aránya kevés. Bár a falu piaci és ellátási körülményei sok tekintetben hiányt szenvednek (tartós vagy bizonyos fogyasztási cikkek), ez mégsem növeli a közlekedési kényszert. A tömegközlekedés leváltása az egyéni közlekedésre, még nem jellemző. Ezért a lakosság hosszabb távú 
mozgásában a tömegközlekedés dominál a ritka járatsürüség és a hosszú menetidő ellenére, ami a személygépkocsik népességhez viszonyított alacsony arányával is kapcsolatba hozható. A fütésből származó alacsony ÜHG-emisszió a lakóházak jellegére, az agrárhulladék jelenlétére és a szegényebb családok anyagi helyzetére vezethető vissza, amelyek miatt az itt élők inkább a fatüzelést választják. Mindehhez hozzájárul az itteni házak müszaki állapota is - rosszabb nyílászárók és szigetelés, nem elég korszerü fütőberendezések -, amelyből adódóan igen rossz hatásfokkal müködik az egyre dráguló gázfütés. Az itt élök még az olcsóbb fatüzelés mellett is takarékosan fütenek, például minimalizálják a felesleges terek fütését.

A harmadik csoport: Érsekcsanád, Sükösd, Nemesnádudvar és Dusnok települések városhoz viszonyított kisebb ÜHG-emisszióját elsősorban a fatüzelésből származó csökkent kibocsátás okozza, annak ellenére, hogy a lakosság közlekedésének és villamosenergia-fogyasztásának kibocsátása a városi és az országos átlagot is eléri. A négy település nagyobb mértékü közlekedési emissziójának hátterében a közeli város által biztosított munkahelyekre történő eljutás, valamint a város által nyújtott szolgáltatások igénybevétele áll. Mindezek egybecsengenek a társadalmi és gazdasági jellemezőkkel: Dusnok alacsony gazdasági aktivitású település, sok az ingázó, ráadásul gyorsan és könnyen elérhető a legközelebbi munkahely lehetőség (Kalocsa). Nemesnádudvaron erös az agrárfunkció, kevesebb az ingázó, viszont a közeli város több szolgáltatást nyújt. Érsekcsanádon és Sükösdön sok a vidéken foglalkoztatott és a legközelebbi város szolgáltatásai könnyen és gyorsan elérhetők.

A villamosenergia-fogyasztás hátterében több mögöttes ok is feltárható, melyek teljes bemutatásához további részletes vizsgálatokra lenne szükség. A szerző viszont a társadalmi és gazdasági jellemzőkkel hozza kapcsolatba a kapott eredményeket. Ezek közül egy lakás komfortfokozata jelentősen befolyásolhatja a villamosenergia-felhasználást. Ennek kiindulási alapja, hogy minél kisebb egy lakás komfortfokozata, annál nagyobb eséllyel már áramellátás sincs. Rém településen a lakások 23\%-ában nincs áramellátás, ugyanakkor a legnagyobb villamosenergia-felhasználó Sükösdön a lakások fele összkomfortos ( $K S H$ 2010). Ez 10\%-kal több jó ellátású lakást jelent Bajához viszonyítva és 30\%-kal többet, mint Rémen. Vagyis a rémi lakosok alacsonyabb környezetterhelése a kisebb jövedelmü háztartásokra visszavezethető komfortfokozat hiányával áll kapcsolatban.

A villamos energia felhasználásának különbségeit befolyásolja még a háztartások alapterülete, a világított helységek nagysága, száma, a világítás módja és az elektromos készülékekkel való felszereltsége. A kissé kedvezőbb társadalmi, gazdasági helyzetű Nemesnádudvaron, Sükösdön és Érsekcsanádon több ember él jól felszerelt lakásmodell szerint. Erre jellemző az újabb és újabb elektromos és háztartási eszközök és gépek vásárlása, illetve a meglévők hosszabb időtartamú használata. Ahogy az egy háztartásra jutó jövedelem nő, úgy növekszik a háztartási gépek állománya, és így a háztartások energiakiadásai is. Azokban a 
háztartásokban, ahol a magasabb jövedelem a hosszú távú gondolkodással és a felelősségteljesebb szemlélettel találkozik, ott nagyobb eséllyel használnak energiahatékonyabb megoldásokat, viszont ez még elég ritka.

Az egységfogyasztás pozitív korrelációba hozható még a háztartásokra jutó lakók számával. A vizsgált települések közül Nemesnádudvaron, Sükösdön és Érsekcsanádon a legnagyobb a 100 háztartásra jutó személyek száma.

\section{Az $\ddot{U} H G$-eredmények az energiafelhasználás függvényében}

A vizsgált tevékenységek országos ÜHG-értékeiről a felhasznált energiamennyiségek (Elek, 2009; Földi, 2011) függvényében a vizsgált tevékenységek alapján a következők mondhatók el (lásd 3. ábra).

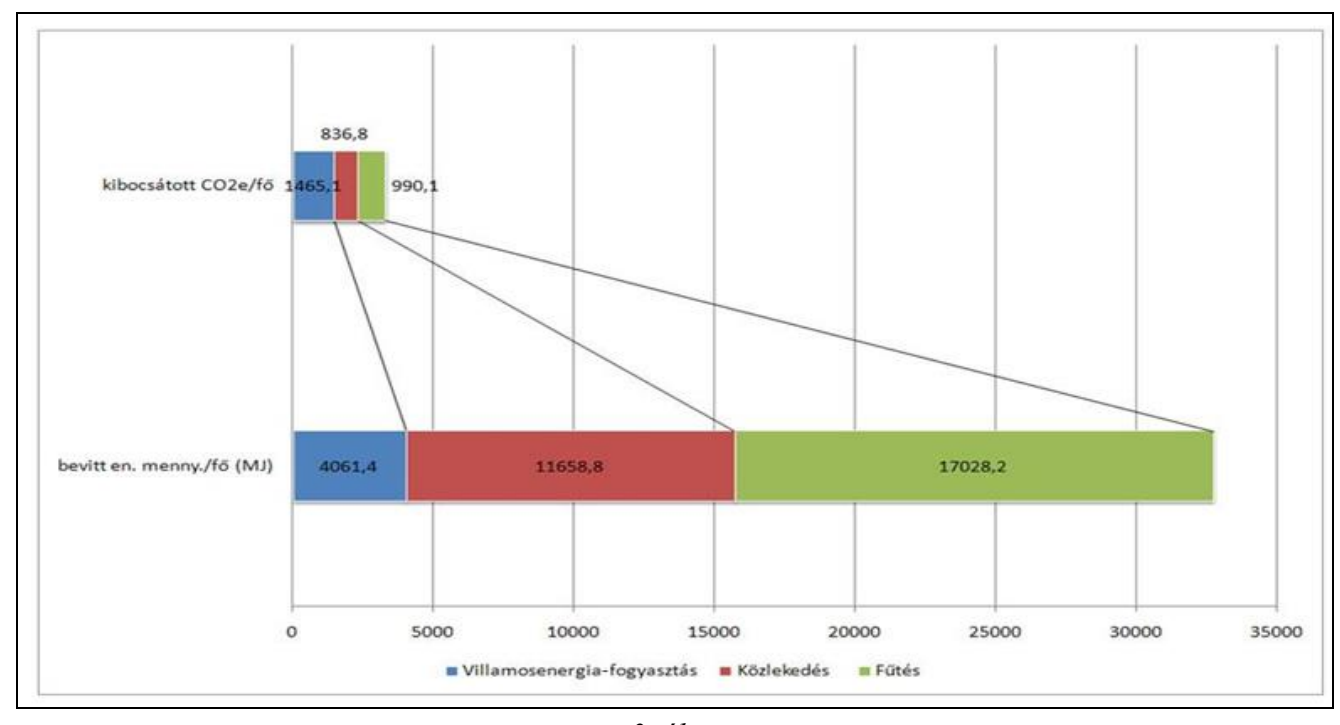

3. ábra

Egy före számitott ÜHG-eredmények és a felhasznált energiamennyiségek összehasonlitása

A vizsgált tevékenységekhez felhasznált energiamennyiségek közül a fütéshez használ fel a lakosság a legtöbb energiát (17 028 MJ), 1,4-szer kevesebbet a közlekedéshez és a legkevesebbet a villamosenergia-fogyasztáshoz. A fütéshez minden bizonnyal még több energia szükséges, mint amennyit a számítás eredményezett. De mivel ez a fatüzelésből származik, ezért ennek ÜHG kibocsátását nem vesszük figyelembe, ráadásul az eltüzelt fa mennyiségét még becsülni is alig lehet. A $\mathrm{CO}_{2} \mathrm{e}$ kibocsátás nem ezt a sorrendet mutatja: a villamosenergia-felhasználásból származik a legtöbb $\mathrm{CO}_{2} \mathrm{e}(1465,1 \mathrm{~kg} /$ fö), ez 1,7-szer több mint a legkisebb kibocsátású közlekedésből származó $\mathrm{CO}_{2} \mathrm{e}$ emisszió (836,8 kg/fö). Tehát fajlagosan a legtöbb ÜHG kibocsátással járó tevékenység a villamosenergiafelhasználás, ezt követi a fütés és végül a közlekedés (lásd 3. ábra). Ezek hátterében a különböző tevékenységekhez használt fosszilis erőforrások fajtái és mennyiségei állnak: mivel a hazai villamosenergia-termelés nagy részét ősmaradványi erőforrások adják és bár ennek tetemes hányada földgáz, de több mint 40\%át kedvezőtlenebb emissziós faktorú energiahordozók teszik ki. A lakossági fütés nagy részét kedvező emissziós faktorú földgáz biztosítja, ezért fajlagosan kisebb 
lesz az ÜHG-kibocsátás. A közlekedés energiaigénye a másik kettőhöz viszonyítva közepes, ÜHG kibocsátása viszont a legkisebb. Ez valószínűleg nőni fog, a személygépkocsi használat várhatóan növekvő tendenciája miatt.

A vizsgált települések közül Baja, Érsekcsanád és Rém ÜHG-eredményeit összehasonlítva a felhasznált energiamennyiségekkel látható, hogy a vizsgált tevékenységek közül a fütés és a közlekedés értékeinek meredeksége a legnagyobb, a villamos energiáé a legkisebb (4. ábra). Ez azt jelenti, hogy energiafelhasználás szempontjából a fütés és közlekedés szélső értékei távolabb vannak egymástól, a közöttük levő különbség fütésnél: $8703 \mathrm{MJ} /$ fö, közlekedésnél: $4242 \mathrm{MJ} /$ fö. A legkisebb meredekség a villamosenergia-fogyasztásnál látható, itt a különbség csak $892 \mathrm{MJ} /$ fö. Ha a szélső értékekhez rendeljük a településeket, akkor a fütés és közlekedés esetén Baja, mint legnagyobb energiafelhasználó $8703 \mathrm{MJ} /$ fö (fütés), illetve $4242 \mathrm{MJ} /$ fö (közlekedés) energiafogyasztás többlettel él a legkisebb fogyasztású Rémhez képest. Ha ehhez még a villamosenergia-felhasználás különbséget is hozzáadjuk, akkor összesen $13837 \mathrm{MJ} /$ fö többlet energiafogyasztással élnek Baján, mint Rémen. Ez a többlet energiafogyasztás 969,3 kg/fö $\mathrm{CO}_{2}$ e terhelést jelent a légkörre évente.

A villamosenergia-felhasználást vizsgálva - mivel ennek függvénye kis meredekségü - az energiabevitel két szélső értéke között jóval kisebb a különbség, vagyis az országos átlagtól csak 892 MJ-lal kevesebb villamos energiával élnek a rémi lakosok. A kis meredekségből adódik az is, hogy kis energiakülönbség is nagy $\mathrm{CO}_{2} \mathrm{e}$ kibocsátást okoz. Mindhárom tevékenység esetén a rémi lakosok energiafogyasztása és $\mathrm{CO}_{2} \mathrm{e}$ kibocsátása a legkisebb. A fütés és közlekedés energiafelhasználásában és $\mathrm{CO}_{2} \mathrm{e}$ kibocsátásában Baja vezet, a villamosenergia-fogyasztás esetén pedig az országos átlag a legmagasabb érték.

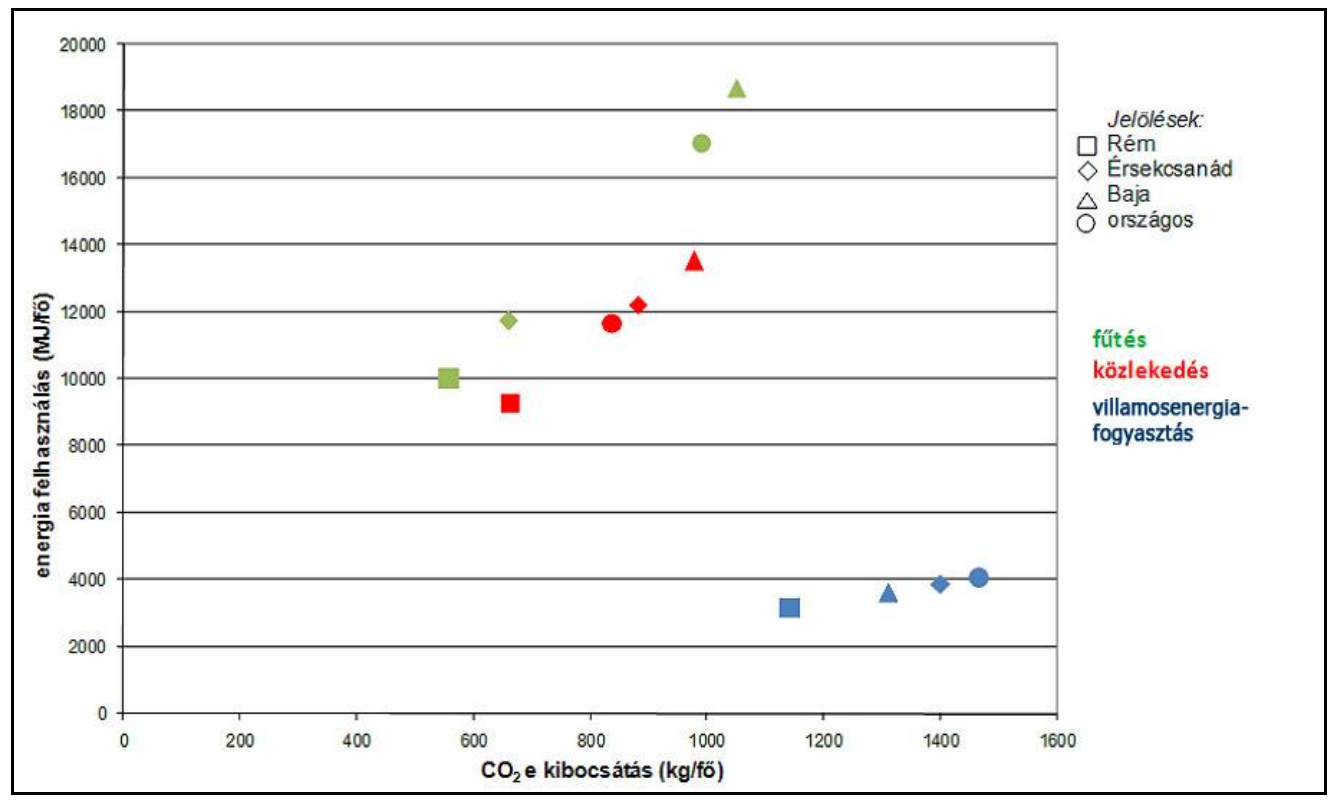

4. ábra

A három kiválasztott település ÜHG-eredményei a felhasznált energiamennyiségek függvényében 


\section{$\mathrm{A} \mathrm{CO}_{2}$-elnyelés növelésének lehetöségei}

$\mathrm{Ha}$ az összlakosság vizsgált tevékenységei által felszabadult $\mathrm{CO}_{2}$ értékeket összevetjük a hazai erdők nagyságával ( $K S H$ 2010), illetve azok $\mathrm{CO}_{2}$ elnyelő kapacitásával, akkor kiderül, hogy a lakosság által kibocsátott $\mathrm{CO}_{2}$-t képes-e a hazai erdőállomány elnyelni vagy pluszterhelést okoz a légkörnek (1. táblázat).

A vizsgált tevékenységekből egy lakosra 3283,9 kg CO 2 emisszió adódott. Ezt az értéket a hazai népességszámra vetítve 32 millió tonna $\mathrm{CO}_{2}$ kibocsátást kapunk. Az OMSZ által figyelembe vett hazai erdők elnyelő kapacitása 3,1 millió tonna $\mathrm{CO}_{2}$ volt 2009-ben. Így csak a legnagyobb energiafogyasztással járó végfelhasználási tevékenységekből 10,6-szor több $\mathrm{CO}_{2}$ keletkezett a lakosság által, mint a hazai erdők elnyelő kapacitása. Ez azt is jelenti, hogy a hazai erdők nagysága nem elegendő a jelenlegi antropogén $\mathrm{CO}_{2}$ emissziót semlegesíteni. 10,6szor nagyobb területünek kellene lennie, ha azt szeretnénk, hogy a kiszámolt $\mathrm{CO}_{2}$ érték ne terhelje a légkört.

\begin{tabular}{|l|c|c|c|}
\hline & $\begin{array}{c}\text { Jelenleg adott hazai } \\
\text { adatok }\end{array}$ & $\begin{array}{c}\text { CO } \text { kibocsátás } \\
\text { elnyelés miatt } \\
\text { szz̈̈kséges lenne }\end{array}$ & Hiány \\
\hline Összerdő terület (ha) & 1890866 & 20043179,6 & 10,6 -szoros \\
\hline $\begin{array}{c}\text { Összerdő terület } \mathrm{CO}_{2} \\
\text { elnyelö képessége (t) }\end{array}$ & 3100000 & 32886038,5 & 10,6 -szoros \\
\hline
\end{tabular}

1. táblázat: A vizsgált tevékenységek során egy lakos által kibocsátott $\mathrm{CO}_{2}$ átváltása erdöterületre

Ha a hazai erdőterület nagyságához igazítjuk a $\mathrm{CO}_{2}$ kibocsátást, akkor 3283,9 kg/fö helyett 309,8 kg/fö kibocsátás lenne megengedett. Vagyis 10,6-szor kevesebb energiafelhasználásból származó $\mathrm{CO}_{2}$ emisszióval szabadna élnünk, mert ennyit lenne képes semlegesíteni a hazai erdőterület.

Ha Magyarország területéhez viszonyítjuk az eredményeket, akkor látható, hogy hazánk 9303600 ha összterületének erdősítése sem oldaná meg a problémát, mert még ez a terület is fele akkora, mint amennyire szükség lenne (1. táblázat).

\section{Összefoglaló}

A hazai lakosság fosszilis erőforrásokon alapuló jelentős energiafelhasználásából származik a hazai összes ÜHG-emisszió fele. Ez az érték a vizsgált városok és falvak között - a falvak javára - különböző eltérést mutat, amely elsősorban a társadalmi és gazdasági viszonyokkal kapcsolatban álló energiafogyasztással magyarázható. A vizsgált tevékenységekből származó emisszió a fosszilis erőforrások fajtáira és mennyiségeire vezethető vissza. A vizsgált tevékenységekből származó $\mathrm{CO}_{2}$ elnyelésére kevés a jelenlegi hazai erdőterület. Ahhoz, hogy legalább a lakossági legnagyobb energiaigénylő tevékenységekből 
felszabaduló $\mathrm{CO}_{2}$ emisszió ne okozzon plusz terhet a légkörnek, feltétlen indokolt lenne az erdőterületek növelése és a barnamezős területek ilyen jellegü hasznosítása. Bizonyos, hogy az erdökön és egyéb zöld felületeken kívül a légköri mozgások és a Föld más semlegesítő potenciáljai is besegítenek a $\mathrm{CO}_{2}$ csökkentésébe. Ettöl függetlenül a kiszámított adatok jól érzékeltetik, hogy a lakosság energiafelhasználó tevékenységeiből mekkora $\mathrm{CO}_{2}$-terhelés nehezedik a légkörre, ami nagy valószínüség szerint megzavarja a légkör dinamikus egyensúlyát, amit egyébként is alig ismerünk.

\section{Irodalom}

Elek László (2009): A háztartások energiafogyasztása. Energia Központ Nonprofit Kft., Budapest.

Földi Gábor (2011 szerk.): A fenntartható fejlődés indikátorai Magyarországon. Központi Statisztikai Hivatal, Budapest.

KSH (2010): Statisztikai Évkönyv. Központi Statisztikai Hivatal, Budapest. 